\title{
Salinicoccus halodurans sp. nov., a moderate halophile from saline soil in China
}

\author{
Xiaowei Wang, ${ }^{1,2}$ Yanfen Xue, ${ }^{1}$ Sanqing Yuan, ${ }^{1,2}$ Cheng Zhou ${ }^{1,2}$ \\ and Yanhe $\mathrm{Ma}^{1}$ \\ ${ }^{1}$ State Key Laboratory of Microbial Resources, Institute of Microbiology, Chinese Academy of \\ Sciences, 100101 Beijing, PR China \\ ${ }^{2}$ Graduate School of the Chinese Academy of Sciences, 100049 Beijing, PR China
}

Correspondence

Yanhe Ma

mayanhe@im.ac.cn
The genus Salinicoccus was proposed by Ventosa et al. (1990) to accommodate a moderately halophilic, Grampositive coccus, Salinicoccus roseus. At the time of writing, eight species of the genus have been described: S. roseus and $S$. hispanicus isolated from solar salterns (Ventosa et al., 1990, 1992; Marquez et al., 1990), S. alkaliphilus from a soda lake (Zhang et al., 2002), S. salsiraiae from salted skate (França et al., 2006), S. jeotgali from jeotgal (Aslam et al., 2007), S. luteus from desert soil (Zhang et al., 2007), S. siamensis from fermented shrimp paste (Pakdeeto et al., 2007) and S. kunmingensis from a salt mine (Chen et al., 2007). During the course of a study of micro-organisms present in the Chaerhan salt lakes $\left(37^{\circ} 03^{\prime} 50^{\prime \prime} \mathrm{N} 94^{\circ} 43^{\prime}\right.$ $41^{\prime \prime}$ E) of Qinghai province, China, various halophilic strains were isolated. Based on preliminary $16 \mathrm{~S}$ rRNA gene sequence analysis, most of the moderately halophilic isolates were found to be related to the genera Bacillus, Halobacillus, Virgibacillus, Marinobacter, Idiomarina and Halomonas. Here we describe the phenotypic and genotypic characteristics of a moderately halophilic coccus, strain $\mathrm{W} 24^{\mathrm{T}}$, which appeared to represent a novel species of the genus Salinicoccus.

The GenBank/EMBL/DDBJ accession number for the $16 \mathrm{~S}$ rRNA gene sequence of strain $\mathrm{W}^{2} 4^{\top}$ is $\mathrm{D} 0989633$.

Transmission electron micrographs of cells of strain $\mathrm{W} 24^{\top}$ occurring singly, in pairs and in tetrads are available as a supplementary figure with the online version of this paper.
Strain $\mathrm{W} 24^{\mathrm{T}}$ was isolated from a saline soil sample taken around the Chaerhan salt lakes by enrichment in liquid medium at $37^{\circ} \mathrm{C}$ and subsequent plating on the same medium with added agar until a pure culture colony was obtained. The medium contained the following (per litre): 7.5 g Casamino acids (Difco), 10 g yeast extract (Difco), $1.0 \mathrm{~g}$ sodium glutamate, $3.0 \mathrm{~g}$ trisodium citrate, $20 \mathrm{~g}$ $\mathrm{MgSO}_{4} \cdot 7 \mathrm{H}_{2} \mathrm{O}, \quad 2.0 \mathrm{~g} \quad \mathrm{KCl}, \quad 150 \mathrm{~g} \quad \mathrm{NaCl}, \quad 0.036 \mathrm{~g}$ $\mathrm{FeSO}_{4} \cdot 7 \mathrm{H}_{2} \mathrm{O}$ and $0.36 \mathrm{mg} \mathrm{MnCl}_{2} \cdot 4 \mathrm{H}_{2} \mathrm{O}$. The $\mathrm{pH}$ was adjusted to 7.2 with $1 \mathrm{M} \mathrm{NaOH}$ before autoclaving at $121{ }^{\circ} \mathrm{C}$ for 20 min. Strain $\mathrm{W} 24^{\mathrm{T}}$ was maintained in this medium supplemented with $30 \%(\mathrm{v} / \mathrm{v})$ glycerol at $-80{ }^{\circ} \mathrm{C}$ for long-term preservation. Strain W24 ${ }^{\mathrm{T}}$ was routinely grown on GMH medium containing the following (per litre): $5.0 \mathrm{~g}$ Casamino acids, $5.0 \mathrm{~g}$ yeast extract, $4.0 \mathrm{~g}$ $\mathrm{MgSO}_{4} \cdot 7 \mathrm{H}_{2} \mathrm{O}, 2.0 \mathrm{~g} \mathrm{KCl}, 80 \mathrm{~g} \mathrm{NaCl}, 0.036 \mathrm{~g} \mathrm{FeSO}_{4} .7 \mathrm{H}_{2} \mathrm{O}$ and $0.36 \mathrm{mg} \mathrm{MnCl}_{2} .4 \mathrm{H}_{2} \mathrm{O}(\mathrm{pH}$ 7.2).

Cell morphology and motility of strain $\mathrm{W} 24^{\mathrm{T}}$ were examined using light microscopy and transmission electron microscopy. Gram-type was determined according to the staining method of Doetsch (1981) and was confirmed by using the $\mathrm{KOH}$ lysis method (Gregersen, 1978). The range of salinity for growth was tested in GMH medium with $\mathrm{NaCl}$ concentrations between 0 and $340 \mathrm{~g} \mathrm{l}^{-1}$. The $\mathrm{pH}$ range for growth was tested at $\mathrm{pH}$ intervals of 0.5 in $\mathrm{GMH}$ liquid medium buffered with $20 \mathrm{mM}$ MES (pH 5.0-6.0), PIPES (pH 6.5-7.5), HEPES (pH 7.0-8.0), Tricine (pH 7.5-9.0) and CHES (pH 9.0-10.0). Growth temperature 
was determined in liquid GMH medium between 4 and $50{ }^{\circ} \mathrm{C}$ by using a temperature gradient incubator (model TN3; ADVANTEC). General biochemical tests (including nitrate reduction, urease activity, $\mathrm{H}_{2} \mathrm{~S}$ production, catalase and oxidase activities, citrate utilization, indole production, Voges-Proskauer reaction, methyl red test, acid production from different sugars and biopolymer hydrolysis) were performed according to previously described methods (Harrigan \& McCance, 1966; Gerhardt et al., 1994; Hezayen et al., 2001). Unless otherwise indicated, all tests were carried out in triplicate in medium containing $8 \%$ (w/ v) $\mathrm{NaCl}$ and incubated at $37{ }^{\circ} \mathrm{C}$. Growth was monitored based on turbidity at $\mathrm{OD}_{600}$. Susceptibility to antibiotics was determined on agar medium plates by using absorbent paper discs impregnated with antibiotic. Tests for use of different substrates as sole carbon and energy sources were performed in modified GMH medium containing $1 \mathrm{~g}$ yeast extract $\mathrm{l}^{-1}$ but without Casamino acids. Substrates in sterile stock solutions were each added to the medium at a final concentration of $10 \mathrm{~g} \mathrm{l}^{-1}$. API $50 \mathrm{CH}$ test strips (bioMérieux) were also used to examine the assimilation of carbohydrates and to examine the production of acid as recommended by the manufacturer, but with a modification that all suspension media supplied by bioMérieux were supplemented with $8 \% \mathrm{NaCl}(\mathrm{w} / \mathrm{v})$ to resuspend cells of strain $\mathrm{W} 24^{\mathrm{T}}$.

Cells of strain W24 ${ }^{\mathrm{T}}$ were aerobic cocci (see Supplementary Fig. S1 available in IJSEM Online). Colonies of strain W2 $24^{\mathrm{T}}$ on GMH agar medium were circular, white, opaque and slightly convex after cultivation at $37{ }^{\circ} \mathrm{C}$ for 2 days. Strain $\mathrm{W} 24^{\mathrm{T}}$ was able to grow at $8-43{ }^{\circ} \mathrm{C}$, at $\mathrm{pH} 5.5-9.0$ and at a salinity of $0-24 \%(\mathrm{w} / \mathrm{v}) \mathrm{NaCl}$. Other phenotypic properties are given in the species description below.

Preparation of the cell wall and determination of peptidoglycan structure were performed according to the methods described by Schleifer \& Kandler (1972) with the modification that TLC on cellulose sheets was used instead of paper chromatography. The amino acid composition of the cell-wall hydrolysate was determined by using onedimensional descending chromatography on cellulose paper. Respiratory quinones were extracted according to the method of Collins et al. (1977) and were analysed by reversed-phase HPLC (Groth et al., 1996). Polar lipids were extracted and identified by using one-dimensional TLC followed by spraying with appropriate detection reagents (Kates, 1986). Fatty acids were extracted, methylated and analysed by GC with the standard Sherlock MIDI (Microbial Identification) system (Sasser, 1990; Kämpfer \& Kroppenstedt, 1996). The genomic DNA G + C content was determined by using the thermal denaturation method according to Marmur \& Doty (1962). The major amino acid constituents of the cell wall of strain $\mathrm{W} 24^{\mathrm{T}}$ were glycine and lysine, which is consistent with the L-Lys-Gly cell-wall type described for the genus Salinicoccus (Ventosa et al., 1990). The major lipoquinone of strain $\mathrm{W} 24^{\mathrm{T}}$ was MK-6. The polar lipid extract contained diphosphatidylglycerol, phosphatidylglycerol and an unknown glycolipid.
The major cellular fatty acids of strain $\mathrm{W} 24^{\mathrm{T}}$ were iso- $\mathrm{C}_{15: 0}$ $(21.85 \%)$, anteiso- $\mathrm{C}_{15: 0}(17.89 \%), \mathrm{C}_{16: 0}(14.33 \%)$, iso$\mathrm{C}_{16: 0}(8.82 \%)$ and iso- $\mathrm{C}_{14: 0}(8.62 \%)$. This profile is similar to that of species of the genus Salinicoccus (Zhang et al., 2007). The genomic DNA G $+C$ content of strain $\mathrm{W} 24^{\mathrm{T}}$ was $45.8 \mathrm{~mol} \%$. The above chemotaxonomic data are in agreement with those described for the genus Salinicoccus.

The 16S rRNA gene of strain W24 ${ }^{\mathrm{T}}$ was amplified by PCR by using the universal primers described by Duckworth et al. (1996). The almost-complete nucleotide sequence (1467 bp) was determined by direct sequencing and was compared with available 16S rRNA gene sequences in the GenBank database by using the BLAST program. Multiple alignment with sequences of closely related species was performed by using the CLUSTAL_X program (Thompson et al., 1997). Ambiguous and unalignable bases were manually omitted and a phylogenetic tree was constructed from the evolutionary distance matrix by using the neighbour-joining (Saitou \& Nei, 1987) method in the MEGA program (version 3.1; Kumar et al., 2004). Robustness of the resultant tree topology was evaluated by bootstrap resampling analysis with 1000 replicates (Felsenstein, 1985). Phylogenetic analysis showed that strain $\mathrm{W} 24^{\mathrm{T}}$ clustered with members of the genus Salinicoccus and formed a distinct branch within the genus Salinicoccus cluster (Fig. 1). Strain W24 ${ }^{\mathrm{T}}$ was related most closely to S. hispanicus DSM $5352^{\mathrm{T}}$ (96.5\% 16S rRNA gene sequence similarity), S. kunmingensis $\mathrm{YIM} \mathrm{Y}^{\mathrm{T}}{ }^{\mathrm{T}}(96.3 \%)$, S. salsiraiae $\mathrm{RH}^{\mathrm{T}}(96.2 \%)$ and $S$. jeotgali $\mathrm{S} 2 \mathrm{R} 53-5^{\mathrm{T}}$ $(96.1 \%)$, and showed levels of similarity of $93.4-95.9 \%$ to the type strains of other recognized species of the genus Salinicoccus. These high levels of sequence divergence $(>3.5 \%)$ with recognized members of the genus Salinicoccus clearly indicated that strain $\mathrm{W} 24^{\mathrm{T}}$ represents a novel species (Stackebrandt \& Goebel, 1994).

The characteristics that differentiate strain $\mathrm{W} 24^{\mathrm{T}}$ from related Salinicoccus species are summarized in Table 1. Differences in several characteristics, such as pigmentation, range and optimal salt concentration, $\mathrm{pH}$ and temperature for growth, hydrolysis of casein, gelatin, Tween 80 and starch, as well as genomic DNA G $+\mathrm{C}$ content and fatty acid composition, can be used to distinguish this novel strain from phylogenetically related taxa (Table 1). Therefore, on the basis of data from this polyphasic study, strain $\mathrm{W} 24^{\mathrm{T}}$ is considered to represent a novel species of the genus Salinicoccus, for which the name Salinicoccus halodurans sp. nov. is proposed.

\section{Description of Salinicoccus halodurans sp. nov.}

Salinicoccus halodurans (ha.lo.du'rans. Gr. n. hals salt; L. pres. part. durans enduring; N.L. part. adj. halodurans saltenduring).

Cells of strain $\mathrm{W} 24^{\mathrm{T}}$ are Gram-positive, non-motile, nonspore-forming cocci, $0.65-0.90 \mu \mathrm{m}$ in diameter, occurring singly, in pairs, tetrads or irregular clumps. Colonies on GMH medium are circular, white, opaque and slightly 


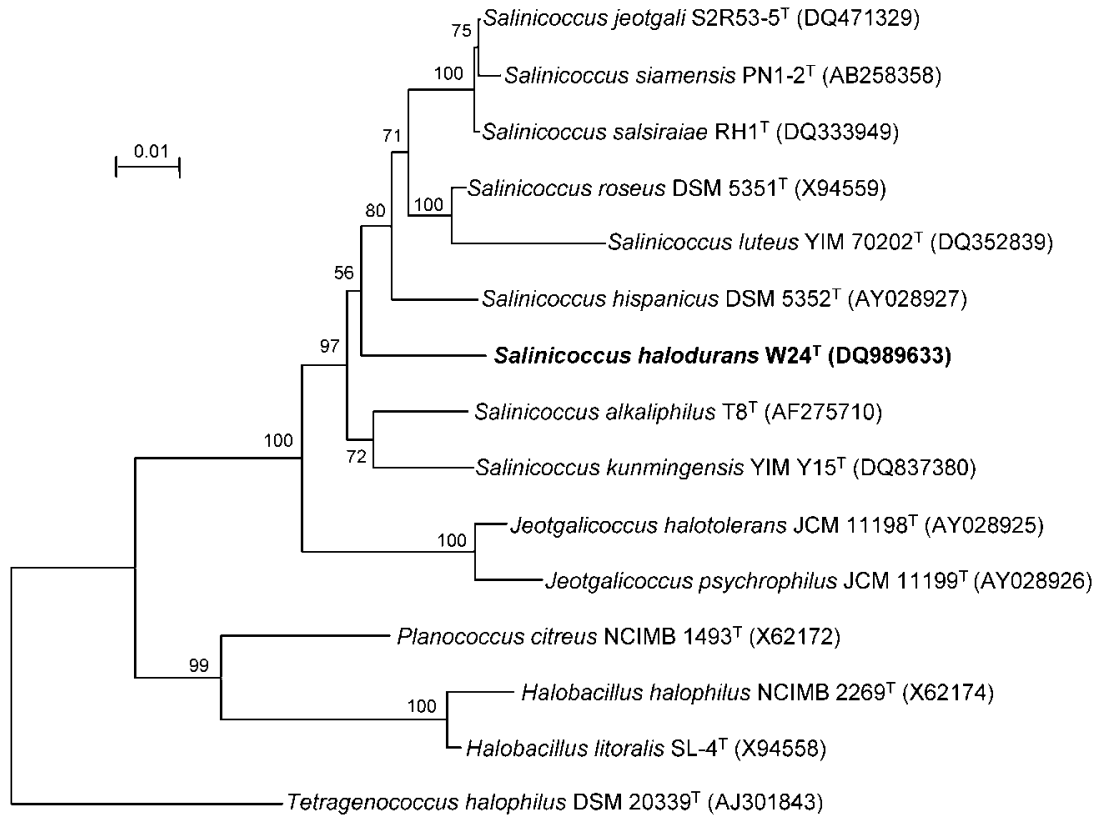

Fig. 1. Phylogenetic tree showing the relationship between strain $\mathrm{W} 24^{\top}$, related species of the genus Salinicoccus and of related genera based on comparative 16S rRNA gene sequence analysis. Numbers at nodes represent levels of bootstrap support (\%), based on a neighbour-joining analysis of 1000 resampled datasets. Bar, $1 \%$ sequence divergence.

Table 1. Characteristics useful in distinguishing between strain $\mathrm{W} 24^{\top}$ and closely related species of the genus Salinicoccus

Strains: 1, W24 ${ }^{\mathrm{T}}$ (Salinicoccus halodurans sp. nov.); 2, S. hispanicus DSM 5352 ${ }^{\mathrm{T}}$ (data from Marquez et al., 1990); 3, S. roseus DSM $5351^{\mathrm{T}}$ (Ventosa et al., 1990); 4, S. salsiraiae $\mathrm{RH}^{\mathrm{T}}$ (França et al., 2006); 5, S. jeotgali S2R53-5 ${ }^{\mathrm{T}}$ (Aslam et al., 2007); 6, S. siamensis PN1-2 ${ }^{\mathrm{T}}$ (Pakdeeto et al., 2007). +, Positive; -, negative; d, differs among strains; ND, no data available. All are positive for Gram-staining reaction, and catalase and oxidase activities, but are negative for spore formation and motility.

\begin{tabular}{|c|c|c|c|c|c|c|}
\hline Characteristic & 1 & 2 & 3 & 4 & 5 & 6 \\
\hline Pigmentation & White & Reddish orange & Pink-red & Pink-red & Orange & Orange \\
\hline Range & $5.5-9.0$ & $5.0-9.0$ & $6.0-9.0$ & $6.5-9.5$ & $6.5-11.0$ & $6.0-9.0$ \\
\hline Optimum & 7.5 & 7.5 & 8.0 & 8.0 & 7.0 & 8.5 \\
\hline \multicolumn{7}{|l|}{ Temperature for growth $\left({ }^{\circ} \mathrm{C}\right)$} \\
\hline Optimum & 28 & 37 & 37 & 37 & 30 & 37 \\
\hline \multicolumn{7}{|l|}{ Salinity for growth $(\%, w / v)$} \\
\hline Range & $0-24$ & $0.5-25$ & $0.9-25$ & $0-22$ & $0.5-15$ & $1.5-25$ \\
\hline Optimum & 8 & 10 & 10 & 4 & 5 & 10 \\
\hline \multicolumn{7}{|l|}{ Acid production from: } \\
\hline D-Glucose & + & + & - & + & + & + \\
\hline D-Galactose & - & + & - & - & - & - \\
\hline \multicolumn{7}{|l|}{ Hydrolysis of: } \\
\hline Casein & - & - & + & + & - & - \\
\hline Gelatin & + & + & + & + & - & - \\
\hline Tween 80 & - & - & + & ND & - & - \\
\hline Starch & - & - & + & - & - & - \\
\hline Nitrate reduction & + & + & - & + & + & - \\
\hline DNA G $+C$ content $(\mathrm{mol} \%)$ & 45.8 & $45.6-49.3$ & 51.2 & 46.2 & 47.0 & $44.5-47.5$ \\
\hline
\end{tabular}


convex, reaching 1.4-2.8 $\mathrm{mm}$ in diameter after cultivation at $37{ }^{\circ} \mathrm{C}$ for 2 days. The temperature range for growth is $8-$ $43{ }^{\circ} \mathrm{C}$, and the optimum temperature is approximately $28{ }^{\circ} \mathrm{C}$. The $\mathrm{pH}$ range for growth is 5.5-9.0, and maximum growth occurs at $\mathrm{pH}$ 7.5. Grows well in media without $\mathrm{NaCl}$. Also able to grow in the presence of $\mathrm{NaCl}$ up to a concentration of $24 \%(\mathrm{w} / \mathrm{v})$, with optimum growth at $8 \%$ (w/v) $\mathrm{NaCl}$. Positive for oxidase, catalase, $\mathrm{NH}_{3}$ production, methyl red reaction, nitrate reduction, $\mathrm{H}_{2} \mathrm{~S}$ production, citrate utilization, urease production, and hydrolysis of gelatin and aesculin, but negative for indole production, Voges-Proskauer reaction, and hydrolysis of starch, casein, cellulose, and Tweens 20, 40, 60 and 80. Utilizes Dmannitol, erythritol, sorbitol, D-glucose, D-fructose, Dmannose, maltose, D-lactose, sucrose, trehalose, cellobiose and L-rhamnose as sole carbon and energy sources, but not lactate, creatine, dodecanoic acids, acetone, ethanol, propanol, pentanol, butanol, iso-amyl alcohol or isopropyl alcohol. Produces acid in the API $50 \mathrm{CH}$ gallery from D-sorbitol, D-mannitol, erythritol, glycerol, D-ribose, D-glucose, D-fructose, D-mannose, maltose, cellobiose, Dlactose, sucrose, trehalose, turanose, $\mathrm{N}$-acetylglucosamine and 5-ketogluconate, but not from D-arabinose, L-arabinose, D-xylose, L-xylose, L-rhamnose, D-galactose, L-sorbose, melibiose, melezitose, gentiobiose, D-lyxose, Dtagatose, D-fucose, L-fucose, raffinose, D-adonitol, dulcitol, inositol, xylitol, D-arabitol, L-arabitol, amygdalin, arbulin, salicin, inulin, glycogen, gluconate, methyl $\alpha$-D-mannopyranoside, methyl $\alpha$-D-glucopyranoside, methyl $\beta$-Dxylopyranoside or 2-ketogluconate. Susceptible to chloramphenicol $(30 \mu \mathrm{g})$, kanamycin $(30 \mu \mathrm{g})$, erythromycin $(15 \mu \mathrm{g})$, tetracycline $(30 \mu \mathrm{g})$, ampicillin $(10 \mu \mathrm{g})$, novobiocin $(5 \mu \mathrm{g})$, rifandin $(5 \mu \mathrm{g})$, vancomycin $(30 \mu \mathrm{g})$, penicillin $(5 \mu \mathrm{g})$ and tetracycline $(30 \mu \mathrm{g})$, but resistant to norfloxacin $(10 \mu \mathrm{g})$, bacitracin $(0.04 \mathrm{U})$, ciprofloxacin $(5 \mu \mathrm{g})$ and streptomycin $(5 \mu \mathrm{g})$. Major cellular fatty acids are iso$\mathrm{C}_{15: 0}(21.85 \%)$, anteiso- $\mathrm{C}_{15: 0}(17.89 \%), \mathrm{C}_{16: 0}(14.33 \%)$, iso- $\mathrm{C}_{16: 0}(8.82 \%)$ and iso- $\mathrm{C}_{14: 0}(8.62 \%)$. Major cellular polar lipids are diphosphatidylglycerol, phosphatidylglycerol and an unknown glycolipid. The major lipoquinone is MK-6. The cell-wall murein is of L-Lys-Gly $y_{5}$ type. The genomic DNA G+C content of the type strain is $45.8 \mathrm{~mol} \%\left(T_{\mathrm{m}}\right)$.

The type strain, W24 ${ }^{\mathrm{T}}\left(=\right.$ CGMCC $\left.1.6501^{\mathrm{T}}=\mathrm{DSM} 19336^{\mathrm{T}}\right)$, was isolated from a saline soil sample around the Chaerhan salt lakes of Qinghai province, China.

\section{Acknowledgements}

This study was supported by grants from the Ministry of Science and Technology of China (973 Programs: 2004CB719605 and 2003CB716001, 863 Programs: 2006AA020201 and 2007AA021306).

\section{References}

Aslam, Z., Lim, J. H., Im, W. T., Yasir, M., Chung, Y. R. \& Lee, S. T. (2007). Salinicoccus jeotgali sp. nov., isolated from jeotgal, a traditional Korean fermented seafood. Int J Syst Evol Microbiol 57, 633-638.

Chen, Y. G., Cui, X. L., Fritze, D., Schumann, P., Pukall, R., Li, H. M., Duan, D. C., Yang, Y. L., Xu, L. H. \& other authors (2007). Salinicoccus kunmingensis sp. nov., a novel halophile isolated from a salt mine in Yunnan, south-west China. Int J Syst Evol Microbiol 57, 2327-2332.

Collins, M. D., Pirouz, T., Goodfellow, M. \& Minnikin, D. E. (1977). Distribution of menaquinones in actinomycetes and corynebacteria. J Gen Microbiol 100, 221-230.

Doetsch, R. N. (1981). Determinative methods of light microscopy. In Manual of Methods for General Bacteriology, pp. 21-33. Edited by P. Gerhardt, R. G. E. Murray, R. N. Costilow, E. W. Nester, W. A. Wood, N. R. Krieg \& G. H. Phillips. Washington, DC: American Society for Microbiology.

Duckworth, A. W., Grant, W. D., Jones, B. E. \& Steenbergen, R. V. (1996). Phylogenetic diversity of soda lake alkaliphiles. FEMS Microbiol Ecol 19, 181-191.

Felsenstein, J. (1985). Confidence limits on phylogenies: an approach using the bootstrap. Evolution 39, 783-791.

França, L., Rainey, F. A., Nobre, M. F. \& da Costa, M. S. (2006). Salinicoccus salsiraiae sp. nov.: a new moderately halophilic grampositive bacterium isolated from salted skate. Extremophiles 10, 531-536.

Gerhardt, P., Murray, R. G. E., Wood, W. A. \& Krieg, N. R. (1994). Methods for General and Molecular Bacteriology. Washington, DC: American Society for Microbiology.

Gregersen, T. (1978). Rapid method for distinction of Gram-negative from Gram-positive bacteria. Eur J Appl Microbiol Biotechnol 5, 123-127.

Groth, I., Schumann, P., Weiss, N., Martin, K. \& Rainey, F. A. (1996). Agrococcus jenensis gen. nov., sp. nov., a new genus of actinomycetes with diaminobutyric acid in the cell wall. Int J Syst Bacteriol 46, 234-239.

Harrigan, W. F. \& McCance, M. E. (1966). Laboratory Methods in Microbiology. New York: Academic Press.

Hezayen, F. F., Rehm, B. H. A., Tindall, B. J. \& Steinbüchel, A. (2001). Transfer of Natrialba asiatica $\mathrm{B} 1^{\mathrm{T}}$ to Natrialba taiwanensis sp. nov. and description of Natrialba aegyptiaca sp. nov., a novel extremely halophilic, aerobic, non-pigmented member of the Archaea from Egypt that produces extracellular poly(glutamic acid). Int J Syst Evol Microbiol 51, 1133-1142.

Kämpfer, P. \& Kroppenstedt, R. M. (1996). Numerical analysis of fatty acid patterns of coryneform bacteria and related taxa. Can J Microbiol 42, 989-1005.

Kates, M. (1986). Techniques of Lipidology, 2nd edn. Amsterdam: Elsevier.

Kumar, S., Tamura, K. \& Nei, M. (2004). MEGA3: integrated software for molecular evolutionary genetics analysis and sequence alignment. Brief Bioinform 5, 150-163.

Marmur, J. \& Doty, P. (1962). Determination of the base composition of deoxyribonucleic acid from its thermal denaturation temperature. J Mol Biol 5, 109-118.

Marquez, M. C., Ventosa, A. \& Ruiz-Berraquero, F. (1990). Marinococcus hispanicus, a new species of moderately halophilic gram-positive cocci. Int J Syst Bacteriol 40, 165-169.

Pakdeeto, A., Tanasupawat, S., Thawai, C., Moonmangmee, S., Kudo, T. \& Itoh, T. (2007). Salinicoccus siamensis sp. nov., isolated from fermented shrimp paste in Thailand. Int J Syst Evol Microbiol 57, 2004-2008.

Saitou, N. \& Nei, M. (1987). The neighbor-joining method: a new method for reconstructing phylogenetic trees. Mol Biol Evol 4, 406-425. 
Sasser, M. (1990). Identification of Bacteria by Gas Chromatography of Cellular Fatty Acids, MIDI Technical Note 101. Newark, DE: MIDI Inc.

Schleifer, K. H. \& Kandler, O. (1972). Peptidoglycan types of bacterial cell walls and their taxonomic implications. Bacteriol Rev 36, 407-477.

Stackebrandt, E. \& Goebel, B. M. (1994). Taxonomic note: a place for DNA-DNA reassociation and $16 \mathrm{~S}$ rRNA sequence analysis in the present species definition in bacteriology. Int J Syst Bacteriol 44, 846-849.

Thompson, J. D., Gibson, T. J., Plewniak, F., Jeanmougin, F. \& Higgins, D. G. (1997). The CLUSTAL_X windows interface: flexible strategies for multiple sequence alignment aided by quality analysis tools. Nucleic Acids Res 25, 4876-4882.
Ventosa, A., Marquez, M. C., Ruiz-Berraquero, F. \& Kocur, M. (1990). Salinicoccus roseus gen. nov., sp. nov., a new moderately halophilic Gram-positive coccus. Syst Appl Microbiol 13, 29-33.

Ventosa, A., Marquez, M. C., Weiss, N. \& Tindall, B. J. (1992). Transfer of Marinococcus hispanicus to the genus Salinicoccus as Salinicoccus hispanicus comb. nov. Syst Appl Microbiol 15, 530-534.

Zhang, W., Xue, Y., Ma, Y., Zhou, P., Ventosa, A. \& Grant, W. D. (2002). Salinicoccus alkaliphilus sp. nov., a novel alkaliphile and moderate halophile from Baer Soda Lake in Inner Mongolia Autonomous Region, China. Int J Syst Evol Microbiol 52, 789-793.

Zhang, Y.-Q., Li, W.-J., Xu, L.-H. \& Jiang, C.-L. (2007). Salinicoccus luteus sp. nov., a novel member of the genus Salinicoccus isolated from a desert soil. Int J Syst Evol Microbiol 57, 1901-1905. 